\title{
Grotesque in the Very Short stories of Palestinian Female Writers
}

\author{
Samah Safouri Khoury \\ Arabic language and literature Department, Haifa University \\ samahkh@gmail.com \\ DOI: http://doi.org/ 10.36892/ijlls.v3i3.551
}

\begin{tabular}{|c|c|}
\hline $\begin{array}{l}\text { Received: } \\
\text { 01/04/2021 }\end{array}$ & $\begin{array}{l}\text { Abstract } \\
\text { This research aims to study the application of the Grotesque technique on the }\end{array}$ \\
\hline $\begin{array}{l}\text { Accepted: } \\
\text { 25/08/2021 }\end{array}$ & $\begin{array}{l}\text { characters of the very short story written by Palestinian female writers. The } \\
\text { study includes three examples of very short stories by Palestinian female } \\
\text { writers from different sectors: Israel, West Bank and Gaza Strip, and the } \\
\text { diaspora. It attempts to find the connection between the grotesque reality that }\end{array}$ \\
\hline $\begin{array}{l}\text { Keywords: } \\
\text { Female, } \\
\text { Grotesque, } \\
\text { Palestinian, } \\
\text { Character, } \\
\text { Very short } \\
\text { story. }\end{array}$ & $\begin{array}{l}\text { emerged after the war in } 1948 \text { and its effects and changes in society, politics } \\
\text { and economics. Therefore, we will monitor the topics written by Palestinian } \\
\text { female writers in the very short story because of the preferences that this } \\
\text { genre achieves that do not exist in other literary genres such as reduction, } \\
\text { brevity, intensification. We reveal the extent to which the Grotesque technique } \\
\text { is used to express marginalized feminist issues, and to find similarities and } \\
\text { differences between stories in the application of the Grotesque technique on } \\
\text { the characters. We found That the Grotesque technique used in the stories to } \\
\text { distort the contours of the characters. The characters do not behave as normal } \\
\text { but are somewhat willful, and act as a mechanism. The character of the } \\
\text { woman is absent and invisible and her voice is inaudible. Women's personality } \\
\text { in various situations is a negative recipient. }\end{array}$ \\
\hline
\end{tabular}

\section{INTRODUCTION}

The very short story depicts several social phenomena and the storyteller tries to express the reality of the individual and society in a satirical way. He also highlights the human being, his concerns, lifestyle, and outdated social traditions that limit his freedom and push him/her towards boredom. Thus, he tries to get rid of all forms of oppression that hinder his creativity, and is concerned with deviating from the socially accepted norm and what has taken root in society as a result of the spread of religious teachings that have become social norms and traditions in addition to being religious (Al-Șamādī, 2007).

One of the important themes revealed in the very short story is the relationship between men and women (Tāhā, 2009), what the male authority exercises over women in terms of authority and control over their fate and the suppression of their psychological and social freedom. Therefore, women play an active role in the very short story, through which they seek to destroy the patriarchal system, which practices its brutality and cruelty on women without any mercy. Thus, she tries to make men weak by destroying the standards of masculinity to which the Arab people are accustomed, since manhood is measured according to the sexual strength of a man, and also the physical one (Tāhā, 2009). Female writers also try to make very basic demands (Tāhā, 2009) such as listening and speaking, which are lacking in many Arab homes, giving themselves the right to express their opinion, and changing society's male orientation.

Many female writers put forward the topic of the relationship between men and women and the obstacles faced by women in society to achieve themselves, such as, its inferiority to them because they are female and its limited vision about them that they cannot engage in any political or social activity. However, they challenge and overcome 
those obstacles to achieve their freedom, so that intelligence prosecutions, investigations and imprisonment are evidence of their freedom (Shablāq, 1996). Female writers also criticize the duality of an educated man who, despite his development and open mindedness about certain social beliefs, still believes that women should serve him despite the sacrifices and revolutionary practices of women (Shablāq, 1996). The author Layānah Badr confirms what is said through a question posed by the narrator in the novel "Būṣalah min ajl abbād alshams" published in 1979, the question is: "when can we live the revolution itself, without being on its margin?". In doing so, she affirms that revolution cannot be achieved without women standing side by side with men, without discriminating or underestimating of them in this struggle.

Many events influenced the writing of the Palestinian women, and sought to shape a different vision of all Arab female writers. The First Intifada, which took place in 1987, was one of the events that influenced women's writing. In many studies, it has been found that female writers have shed more light on women's issues and concerns than on general social issues, and there has been little mention of political issues and real-time events (Gottesfeld, 2010, Gottesfeld, 2013). Among the things that the Palestinian writer has accorded great importance to topics related to love and sexuality and the land registry guidance that she never fought directly. However, the opportunities to learn and work have greatly affected her and changed her perceptions of things, so she comes out more daring and free to express herself (Gottesfeld, 2013). However, it has emerged that the writer who lives in the occupied territory, or in the West Bank and Gaza Strip, was less daring than other Arab female writers in various Arab countries. She has avoided the use of the intimate words, rude and harsh language and topics that are considered sensitive in the society. This is because she lives in a traditional and small society, which requires her to be more careful in introducing topics and picking out the right words (Gottesfeld, 2013).

The reality that emerged after the 48 war and the establishment of the state of Israel has spawned many of the themes that have really emerged in the very short story, because it is the one that is best able to convey the living reality with all its contradictions and to express the current issues of concern to the human mind. The very short story has all the conditions to connect the multiple voices in society and aims to highlight all marginalized topics and give them room to float to the surface and have a platform.

In our current research, we will try to study the reflection of the grotesque reality in the very short story of Palestine and the extent to which the Grotesque technique is applied on the characters of Palestinian female writers. This is because we believe that the grotesque reality that Palestinian women are experiencing can also screen grotesque personalities, which are outside of norms and traditions, eccentric and ugly, and full of contradictions and depict the tragedy of a marginalized and frustrated person.

\section{THEORETICAL BACKGROUND}

The art of Grotesque is achieved through several basic principles, the most important of which are:

1. This art is contrary to the normal classifications that man has made for each definition (Harpham, 1982). It's a "non-thing" and it doesn't fit our classifications of real things. It is not normal and when we experience it, we feel challenged and humiliated, so we begin to classify it as Grotesque (Yates, \& Adams, 1997).

2. Grotesque happens when there is a gap between what happened and what will happen; this gap is the way to discover the new look (Harpham, 1982). The difficulty of this new look is that it generates contradictory feelings such as joy, sadness, horror, absurdity and other emotions in which the mind is in a phase of balance between death and resurrection, madness and revelation, demolition and dissoluteness (Harpham, 1982). 
3. The art of Grotesque is a new vision and is a revelation of a hidden truth, in that through fighting the demonic elements that exist in the world we can be liberated (Harpham, 1982). It is also a generator of a new meaning because through the combination of different elements such as human and animal confirms the existence of another place different to this world, which requires a review of many values and theories (Hībī, 2012).

Character in Harpham's art of Grotesque is divided into two groups due to changes that have occurred in the currents in the last century, including the bourgeois, capitalist, fascist, and other currents that sought to increase divisions in man (Hībì, 2012). Therefore, conflicts arise in the mind, sensations and feelings of man, leading to a Grotesque of thoughts, a disturbance of natural feelings, and a dislocation of the dark aspects of the human soul (Hībī, 2012).

The research is divided into two sections the first one is the theoretical section in which the definition of the technique of Grotesque and the purpose of its use in various arts, and the need of the authors for this type of techniques will be presented. The second section, is an application section where we will address three very short stories of Palestinian female writers from three different sectors: Arab citizens of Israel, Palestinians living in the West Bank and Gaza Strip, and Palestinians living in the diaspora, and we will monitor the extent to which the Grotesque technique is used in the characters.

\section{Indifference to Brutality}

In the story "Mashāhid min Masrahiyyah Fukāhiyyah" (Scenes from a Humorous Play), the Jordanian Nabulsi writer Sāmiah al-'aṭ ūt presents the subject of violence in society and the difficulty that people face to deal with it and accept it, and they try to deny what is happening through their preoccupation with means of communication that can also weaken their human feelings.

\section{Scenes from a Comic Play}

\section{Scene one: bowels}

He jumped like a panicked cat, hiding his face between his palms from the horror of the scene. He didn't believe what his eyes see. His mother's bowels were coming out of her belly, while she was standing in the middle of the road trembling between street intersections and traffic lights. She stood in the middle trying to cross towards any sidewalk. She held her loose bowels in her hands and no one stopped to see her. She was dragging herself, so as not to fall to the ground.!!!

The son looks at her like a paranoid cat.. Think.. There are still two streets separating them. He won't get there quickly, and she might fall unconscious on a dirty ground full of remains of human bowels.

He felt nauseous..

And suddenly, his bald head had an idea. He took the mobile out of his pants pocket. Called customer services quickly. The voice answered very smoothly, to inquire click one, to fill your balance click two, for services of the.. Press three,.. For packing .. And, before he completed his options, he received a snapshot via Bluetooth for (a thirsty monkey). $\mathrm{He}$ received it hastily, and when he opened it, he couldn't control himself and burst into 
laughter. He laughed so much and so long that he lay on his bald neck and head, and he never hesitated to send it urgently to a number of friends!

\section{Scene two: bus}

Catched the door of the bus, while she completes her walk. It was full of passengers, and their noise doubled its weight.!!

He kept holding the bus door with his left hand, while holding his books with his right hand. He tried to push his huge body, heaps of fleshy bodies, trying to find a place inside, but in vain.

Suddenly, a car approached the bus. He beholds two bearded men inside it; one wearing a turban on his head, while the other clamp his hat with pins, and then we heard a huge explosion and a dense smoke... we were stunned.

Did the bearded men blow up the bus??

Did the bus blow up the car with the bearded men??

Was it a thunder sound somewhere nearby??

All I know is, I saw with my own eyes the bodies strewn in different directions.. The meat sticks to the iron, and the iron is stained with blood.. And I saw from afar, that lady holding her loose bowels in her hands and dragging herself tired.

I smiled secretly and turned my back on the whole scene...!

\section{The last scene}

We're here around ..

We feel some cold, while it is igniting outside and everything is burned.

Food and drug prices are rising .. And chickens that don't die with flu die with our incinerators..

Cities are burning to the ground ....

And prices of the oil ignite before it reaches our stoves...!

It's moments we steal to lose sight of reality, you and I.

And the last scene remains, that we'll get out of here, alive or dead, so that the cold and strange streets will hug us again...

We get lost between a Hookah cafe, an internet cafe and cafes with no seats or cups of coffee and tea.. 
The final scene remains that, however we turn, we will return to a chill that strikes us in reality, away from the warmth of dreams and fantasies" (Al-ait'üt, https://www.intelligentsia.tn).

Author Sāmiah al-ațūṭ divides her story into three scenes and each scene deals with the subject of a bomb explosion from a certain point of view. The first scene begins: "bowels" with a depiction of an explosion that occurred in the street and a young man sees his mother injured by the explosion. Thus, he feels stunned from the horror of what he sees and tries to reach the mother who carries her bowels in her hands and tries to cross the street. However, he feels nauseous from what he sees, so he preoccupies himself with recharging the mobile phone, then a picture of a monkey jumps out and he laughs at it a lot and sends it to his friends.

In this harsh scene that shows the brutality of reality that the innocent people fall victim to, we see that a person also has distorted concepts and feelings. At first, the young man who sees his mother holding her bowels in her hands is depicted as shocked by the sight of his mother, who is a victim of an explosion and who tries to stand and cross the street, but no one tries to help her or go to her. She is alone despite the suffering and the pain, and people do not care for her or try to help her. Her son initially tries to reach her before she falls on the earth contaminated with human bowels. He is afraid for her and thinks and cares about her, but at the same time he is afraid that she falls on the earth and is contaminated. This is a very secondary and unimportant matter as opposed to her safety and health, which he must care about first of all. The second thing he is preoccupied with is the phone he wanted to use. Maybe he wanted to receive help or to call first aid, but the phone answers him in a way that is lacking in sensations and feelings. Time is the greatest enemy of the injured in that situation and he must use it as much as possible to get the appropriate treatment before it is too late. But the automated response used to respond to users is the one that judges the woman to die as a result of the cold response and the indifference to the situation. The young man as a result of his nausea tries to escape from the brutal and painful reality using the phone that completely makes him forget about the situation in which he is. The third thing that preoccupies him and keeps him away from the event altogether is the arrival of a snapshot of the thirsty monkey via Bluetooth, which shows a monkey drinking his urine as a result of thirst. Thus, the young man bursts into laughter and lies on his back as a result of his intense laughter. It is clear from this that the smart devices used by man seek to bring him out and remove him from the tensioned atmosphere, the miserable conditions and the grotesque reality suffered by man that manipulates his feelings. Thus, he becomes like puppets that the devices move with strings, mess with their feelings and undervalue them. What is painful is that man responds to them and does not judge his mind in those situations that require a quick reaction to a tragic event.

In the second scene, the narrator does not only convey the scene but becomes an accomplice in the event and depicts the bus carrying passengers exploding as a result of a terrorist act when a car passes by bearded men. However, he cannot accuse them because he does not know whether it is the bus or the car that is exploded. It is nonetheless, clear that they have a hand in the matter and their appearance suggests that. The world always points the finger at religious people because they believe that religiosity will inevitably lead to radicalization and extremism at a certain point, so it is easier to accuse those whose appearance suggests that than to accuse a normal person in fashionable clothing. All these images have led the narrator to many questions that show his surprise and the difficulty he faces to receive this horrific scene that has killed so many innocent people. Thus, it becomes easier for him to refer to these two people than others. If we look at it, it describes 
extremists who carry out atrocities against innocent people, who pay a price for the policies of states and governments, which takes lives and sheds blood unabated. The narrator once again highlights the woman holding her bowels in her hands, so he does not care about her, smiles secretly, and then completes his walk and turns his back on this entire painful scene.

The narrator expresses in this scene another Grotesque of man when he does not care about everything that is going on, and does not provide assistance to anyone, and does not feel any responsibility towards the victims and innocent people whose blood is seen everywhere. He is numb and does not care about all that is happening. Rather, he is content with wondering and referring to the people responsible for all these atrocities, but he is no less brutal than them because he expresses his indifference, his rigidity, and his mockery as well. He depicts the woman without expressing his feelings about the scene and is satisfied with describing her as being tired as a result of carrying her loose bowels. This description is rigid and devoid of any feeling with the other, but the narrator smiles and leaves the place just as her son did, who cared about charging his cell phone and receiving funny pictures that are not related to the situation.

In the third scene he depicts the reality that man has come to as a result of the magnitude of the misfortunes that occur. He feels the moral cold as a result of people's indifference to each other and indifference to the prices of medicine that the poor cannot get, and indifference to the suffering of animals and birds as a result of human torture, and the wars that affect the cities and burn them all which makes the man has no safe place to live in. The feeling of physical cold is also the result of high oil prices, which makes it difficult for the poor man to refuel for heating. That reflects the extent of the deterioration of people's conditions, their lack of interest in each other's affairs and the state of anesthesia in which they live without any concern for the horror of the blows afflicting them. The final result in the scene is either death or life. In both cases, man will be feeling alienated and lonely in this world despite his attempt to entertain himself with the pleasures of life such as hookah, internet, cell phone and so on. Man tries to occupy himself in various ways and means, and to pursue his dream or fantasies that are impossible to realize but make him feel somewhat warm. In the final scene, however, all of these things mentioned will be far away, and the feeling of alienation and loneliness remains overwhelming.

Many techniques are used in this story, including Grotesque of the characters. In the first and second scenes, the writer is concerned with character Grotesque by highlighting the contradiction between the human qualities that had to be demonstrated and the lack of humanity of the young man in light of this reality that produced this kind of people, who no longer feel anything because of the many blows and the horror of misfortunes they face. In the first scene, we see the indifference of man to the closest person to him (his mother), whom he must be driven by his instinct to protect and help, but the instinct is also grotesqued and no longer present in this reality. In the second scene, the stranger deals with the same situation in the same way and without any care, but makes speculation about who is responsible for the situation, and is content with this amount of information and completes his day as if nothing has happened. In the third scene, we see the philosophical dimension of the previous two scenes and their explanations and interpretations of what man has reached under this reality of psychological alienation and objectification of all the characters that are no longer pulsating and excited under these circumstances.

The title reflects alienation that the characters in this world suffer from until they see all events as a play in which they cannot take a major role, and the audience cannot interfere with it and change the course of events. The play is an unrealistic and imaginative event, so people see that these things are like drama that it is difficult for them to digest its harsh realism and deal with this amount of painful scenes, so laughing and smiling are the most that can be done when witnessing this pain, perhaps because the man has reached a state of extreme despair and there was no glimmer of hope to change the status quo. 


\section{Primitive Men}

Author Șabāh Al-Qallāzīn from Gaza poses in her story the subject of the suffering women face in our society as a result of the underdevelopment of men and their inferiority look. They look at her as a thing and try to deal with her body as a sexual object no more. They also see her as an easy prey to get after lust stirred them, so each of them, without any exception, proceeds with his plan to undermine her, and think about how to obtain her body without any deterrence or supervision (Benmaśūd, 2006; Nàjī, 2002).

\section{Dissoluteness}

"In our depths, forests have not been trimmed, predators are waiting for the moment of pounce, and primitive naked men are throwing fire. Thus, when the girl with skinny jeans and a pink blouse and a sculpted body went to the toilet to renew her decoration, the eyes came out of their orbs like sewers as she recites her unhurried step on the slippery marble floor of the cafe. And since vulgarity celebrates secrecy, every man in complete safety has prepared his infernal plan to have her alone and on low heat" (Al-Qallāzīn, http://anfasse.org/next51-osaka/xmkb1-240001152802/4450.html).

The author opens the story with a deeply poetic sentence, where she likens the depths of man to the forest that has not yet been trimmed and which branches have not been trimmed as well, so it will be on its own without being monitored over its actions by anyone. By this, she refers to both women and men, in that the instinct still controls the human being and likens it to a predator who has the opportunity to capture and win his booty alone. These two sentences reflect a deep thought and philosophy in which the text opens to activate the senses and the operation of thought and imagination so that the semantics of the vocabulary are broader than that of the lexical semantics (Mabrūk 1989; Hamdāwī, 2012). This opening is used to convey the desired meaning of the story and to shape the initial picture of the underdevelopment suffered by society and man, and presents an initial grotesque picture of the man who wears the dress of urbanization but practices underdevelopment in his actions. And then she completes the sentence with the same idea but proceeds to the narration of the actual event. The third sentence highlights the category of men who are still primitive, lighting fire with a stone mug. The author portrays them as nudes who have not yet learned modesty, because in their actions and nature they still live as in the Stone Age and have not evolved with the development of time. After describing the beginning experienced by men in particular, she moves on to another scene. Here, she links the two scenes with the word "so" which indicates the result of the previous sentence, and places a comma between the two sentences to indicate the cause-effect connection. The author describes a girl walking down the street and describes her clothes very accurately. She shows the obvious paradox between male nudity in the previous sentence, which shows the beginning of their life and the era in which they are still living, and the modern fashionable clothes worn by the girl, which shows her femininity and her clearly svelte body. Although she is dressed, they look at her body and perceive it in all its details, and their eyes pop out as they watch her. The writer describes the men's eyes as sewers to show their atrocity and apparent ill intention as she walks through the cafe. Despite the formal development of society, which allows the presence of women next to men in the coffee shop, and the modern dress worn by the girl, all men behave clearly barbaric. This shows the horror of what they think and their inferior look towards the woman and her body.

It is clear from the author's description of the girl's movements that she is uncomfortable in her walk, so she walks slowly in order not to fall on the floor. We notice here that men take advantage of the situation to observe all her movements, as if they are in 
front of a model whom they have to criticize from head to toe and point their eyes at her figure. Although the girl is in trouble because the ground is marble, men do not care about this matter. They rather look at the event in a dreamy way, far from reality. In the last sentence, the author uses the sudden ending to show the terrible thinking of men and their real nudity. It is revealed by their looks towards the girl, and their poor thinking about her until each of them imagines the plan that he must devise to get the girl. It turns out that all men think the same; they see the girl as a prey that must be taken away because of their primitive nature. This is the nature that the author mentioned at the beginning of the story, in that they wait for a favorable opportunity to pounce on their prey.

In this story, the author uses the method of Grotesque of the human in general and man in particular. She depicts man as still primitive, living a forest life that is controlled by his whims and desires, and pushing him to do what he wants without being watched over his actions Forest life requires man to eat or to be eaten, and therefore man must have courage and strength to ensure his survival in this world. However, the author portrays man as an animal, too. Here, we notice how much she degrades man's status and sees him as a predatory animal, whose heart has no mercy or compassion for his brother man. She highlights men, portrays them as Neanderthals and demeans them in several likenesses, showing how terrible they look at the girl by likening their eyes to sewers. The author uses here a disgusting description of the eyes of men in order to indicate the dirtiness of their looks and their poor thinking of the girl. Therefore, the author gives disgusting descriptions to ugly the image of men, and to destroy their image by which they delude people. Thus, the descriptions are filled with the dirtiest images to express their bad intentions. The last sentence showed that their image was scandalous. Although they kept their intentions as a secret and covered up their obscene ideas, the sewers could not cover up their own smell. Anyone who smells the smell knew firsthand the source and location of the smell. And that's why all their intentions are exposed as a result of their dirty looks, and it turns out that the narrator is sure of what is on their mind after their looks have revealed them. The author uses many words and expressions that show that the girl fell prey to polytheism as her use of: "to receive", "to celebrate", "hellish plan", "low fire", "to get her". This shows how brutal and demeaning they are as men. They treat her as a senseless thing, they even see her as food that must be cooked on a low fire so that they can eat it and satisfy their instincts and extinguish their eternal hunger to the body.

When reading the title "Dissoluteness", a female image comes to our mind directly, but it is clear from the story that the way men are thinking is the dissoluteness and not the girl. Therefore, the title reflects a modern paradox between what is expected and what is actually happening. Women have developed over the ages and have become civilized while the man is still living in the Stone Age. The man looks at her with an inferior look that reflects his immorality and bad faith. Society highlights the actions of women and their clothing and accuses them of dissoluteness if they wear what they like while men remain free. Free in their movements, actions and thoughts. No one judges him or gives him a note on his actions or looks. Women must take caution in all their actions so as not to arouse the lust of men and provoke his whims. Therefore, the title reveals the grotesqued view of women by the whole male society. Since women are vulnerable, they must behave and dress in accordance with the reactionary male thought in order to protect their evil and save herself from their actions.

\section{Family Violence}

In her story "Hawwà Taghushshu Al-hikāyah" (Eve Cheats the Tale), the writer Anwār Sarhān from Nahaf village presents a collection of tales numbered from one to four each dealing with a different theme. In this story, Anwar addresses the subject of receiving the girl in the Arab family in a very controversial and strange way. 


\section{Eve Cheats the Tale}

\section{1- A Tale}

"My mother was hungry and bereaved, before the news of me being a female broke her. She leaned over the umbilical cord, snapping it, and her face was covered in blood. The midwife jumped out as she was flinched with surprise. She wandered in the streets of our town swearing that we were a savage breed, leaving half the rope running out of my belly like an old male betrayed by his manhood. My mother kept chewing what she swallowed from the bitten piece. And in vain my father beat her, so that she might be persuaded to eat alternative meals. She swore that she would never forgive herself for having children who endured all these ills.

As I spent my years trying to cut the rope that had rotted. Every time I got rid of some of it, there was new blood.

The sound of the midwife still smacks me. And my dad's manic blows on my mom's mouth didn't stop me from screaming. While my teeth, which whenever they grow, they become broken, keep making fun of my failed endeavors" (Sarḥān, https://www.facebook.com/profile.php?id=100010207990224).

The mother is depicted in this story as a dangerous monster. After she knows that the newborn is a female, she started biting the umbilical cord to get rid of her daughter to whom she gave birth, while the father tries hard to save the girl from her mother. He could not, so he tries to beat her until she stops doing so. In the second paragraph, the narrator completes what the mother has begun to try to get rid of her life, but her attempts also fail because her teeth are broken.

In her story, the author describes the grotesqued reality of the Arab family, which produces brutal and evil mothers. Instead of giving love, attention and care to her newborn, the mother seeks with all her powers to get rid of her daughter using all available means to get rid of the "tragedy" she suffered. The birth of the girl for her is a great tragedy, and therefore, according to her, bearing the pain of childbirth was in vain because she was waiting for a male, not a female, to be compensated by her hunger and pain. The narrator depicts the moment when the mother swoops on the umbilical cord in a brutal, violent, bloody moment. This contradicts the usual notions of motherhood upon which we grew up and in which every woman seeks to protect her child from harm, to take care of it and to provide everything necessary for it to be raised properly. And we notice here a clear paradox in the situation where the event that the reader expects from a mother who gives birth and wants to hug her baby to her chest to give him tenderness and care and with the actual situation expressed in the story. This situation reflects the brutality of the mother and her assault on the rope to cut it, so that the scene fills with blood, not tenderness and compassion. Thus, the reader is surprised and tries to solve the mystery in the story until the picture is complete (Shawkī 1988; Al-Khamīs 2016; Mīnū 2000; Cuddon, 1998).

The second role played by the female in this story is the role of the midwife who is shocked after seeing the mother swoop on the umbilical cord. As a result of her shock, she escaped from the place to express her lack of acceptance of what has happened and her inability to comprehend, and that what the mother did is beyond the limits of logic and humanity. But she didn't try to save the newborn from the mother as she has left the baby with the umbilical cord hanging in her belly. Here, we note that there are many women who express and profess their vulnerability, and who exploit women who are out of the will of 
society to gain points in the masculine society. Thus, that women stand with men and strengthen their position rather than supporting the girls who are of her own gender.

The third personality that appears in this story is the father who represents the males in the society, but she describes him negatively despite his positive goal. He treats the mother violently and hits her so that she may stop doing it and eat other meals. We see that the father in this story does not understand the causes of the mother's action and the causes of the problem and tries to beat her despite being the first and last responsible for the mother's condition. The mother is trying to protect her daughter from "bearing all these ills" because she believes that women in this society bear a lot of the burdens. Thus, the mother believes that it is better for the child to die than to live in a society that demands a lot from her, treats her violently, and degrades her wherever she exists. In the second paragraph, the narrator shows how cruel father is while beating the mother on the mouth as if he does not want her to express what is on her mind, to accept the injustice suffered by women, and to suppress her anger and grief forever and not to pass it to her daughter.

The author uses caricatured descriptions as well as Grotesques, so if we look at the description that she gives to the umbilical cord attached to the newborn "an old male betrayed by his manhood", we found it funny and caricatured. It carries with it a mockery of the male organ and disguise the position of the umbilical cord attached to her body, which resembles a male organ. Therefore, she expresses her inability to bear its presence or to look at it, or her ability to accept it as part of her body because it resembles a penis. Here, we note the disregard for all the signs of masculinity, which feminist writers have sought to highlight in order to devalue the organ as much as possible to humiliate the man and to underestimate his physical strength represented by his sexual strength.

In a study of Ibrahim Taha (2006) he indicated that a lot of Arab writers described the man's sexual organ with funny descriptions and it is clear from these descriptions that they ridicule this organ. Although a man is proud of this organ because it is a symbol of masculinity, the woman makes the man's organ a symbol of his weakness and a proof of his failure in front of the female's body and the steadfastness of her thin membrane in front of his organ. Here she emphasizes the demolition of this patriarchal system that makes the man a symbol of strength and virility.

What is surprising about this story is that in the second paragraph the narrator talks about her repeated attempts to cut the rope, but each time she fails. Each time she revisits the scenario presented in the first paragraph to show how the first scene affected her as a female and that she still looks at herself from the same perspective as her mother. This inferior view of herself made her think about cutting the rope again despite its rottenness, and the fresh blood flowing from it. This indicates that she does not despair of her attempts, but her struggle is no longer with the father but with her body, which refuses to get rid of the umbilical cord, which for her is a disgrace. It is the basis of her existence in life, yet it reminds her of the loads and burdens that her mother talked about, and her mother agrees to that and strives to get rid of these loads.

Teeth and mouth play a key role in this bloody struggle, and the narrator portrays the teeth as constantly growing and breaking and this indicates her weakness as a female in the challenge. Although she wants to be free from the rope, her body betrays her and every time she tries to do so, she fails and breaks her teeth, which symbolize strength and challenge. This break of teeth is inherited by the daughter from her mother as a result of the father's beating of the mother and therefore also inherits weakness and inhibition. Despite her repeated attempts, she fails every time since the woman's body betrays her every time and shows the strength of the man in front of her strength and life force in front of the forces of death. And every time the mouth is responsible for this failure. When a mother gave birth, the father hits her on the mouth which tried to get rid of the umbilical cord. In the second time, the girl tries to get rid of the umbilical cord with her teeth but her teeth are breaking 
and making fun of all her attempts. Here, we note that the author highlights the mouth and the umbilical cord and neglects other organs in the body, both of which provide the body with all the food and oxygen it requires, whether it is for the mother or the fetus and ensure their survival. Therefore, the mouth aligns with the umbilical cord and refuses to be cut as well as the teeth break all the time. It turns out that no matter how much a woman tries to stop the life cycle and stop giving birth to girls, the will of God is stronger than the will of the female who tries to stop her motherhood, her life, and the sacred role that God has endowed her with to complete her job.

The writer applies the method of Grotesque on the characters of mother and daughter, who do not behave normally, but their behavior is surprising and scary. As if we are in front of a nightmare or a horror film played by the characters, no desire to do so but the reality imposed on them, which produced women with such brutality in dealing. They rejected all that is acceptable and instinctive and declared inability to absorb more pain and burdens imposed on women. Therefore, women are always ready to fight their existence and the existence of others in order to ensure the safety of their daughter from the following, as well as the girl is eager to save the future generation. The imposed reality does not give women a choice but directs them to the same fate, either they decide about it or the male society decides to bury them. The infanticide of girls was an ignorant habit by Arabs to get rid of females in the family, but today women strive to infanticide their own gender because they know what will happen to them in the future. There is no dialogue in this story and it is dominated by a violent, charged, bloody atmosphere provided by the mother. The midwife who slaps the girl, then the father and then the girl who grew up in this blood-charged atmosphere and she does not realize another way of expression other than biting, snatching and bloodshed. This violence is directed at her. We see her seeks to promote it by abusing herself, denying herself, and treating herself as an enemy. She does not feel the pain or express it, but feels alienated from her body and teeth in particular, such as saying: "she keeps making fun of my failed endeavors". Here, we note her repeated failure as a female to control her own destiny, like her mother's earlier failure.

\section{CONCLUSION}

It turns out through my study that the three women writers Sāmiah Al-ațūt Anwār Sarhān and Șabāh Al-Qallāzīn applied the technique of Grotesque on the characters at various levels. It turns out that the characters do not behave as normal but are somewhat willful, and act as a mechanism without having any human sense. This was demonstrated by the indifference of the son towards his mother in the most difficult moments in the story "Scenes from a Comic Play", and the indifference to the automated response invented by man, so we see it standing as a barrier in front of him, transforming critical turbulent events into cold and unnecessary moments. We also see in the story "Eve Cheats the Tale", the use of the insane and brutality in the mother's quest to cut the umbilical cord of her daughter in order to kill her, and her daughter's repeated quest to get rid of this cord that remained stuck in her. In the story "Dissoluteness", the woman's body is presented as a thing and she is seen as the engine of dissoluteness, but in fact it is the men who are morally corrupt, and it is they who are provoked without exception by the mere sight of a woman walking in front of them. Their gazes and movements are described as sewers, and in this description, there is a Grotesque of the man's personality in general and a focus on the negative aspects of his behavior, views and ideas that pollute society.

The Grotesque technique is also used to distort the contours of the characters and the details of their body as a result, and this Grotesque arises after they are subjected to physical and verbal violence and degrading looks by man. This violence takes place in several places 
and levels, and does not end once the story ends, but rather it is continuous and not final. The family also contributes to feeding and intensifying violence. The father, mother and son in the stories "Scenes from a Comic Play" and "Eve Cheats the Story" do not make her feel safe. And here we have the enormity of the insecurity suffered by man, especially in the place that must be the safest and warmest, neither the house can provide security nor the street, we find her deformed and violated in various places. In the story "Scenes from a Comic Play", the mother's body is depicted with the ugliest depiction as in the following scene: "she held her loose bowels in her hands, no one stopped to see her, dragging herself, so as not to fall to the ground.!!!" In the story of "Dissoluteness" the men's gaze resembles a sickening distorted analogy, as in the following sentence: "the eyes have come out of their orbs like sewers." In the story "Eve Cheats the Tale", the scene of the birth of the girl is depicted as a brutal moment in which the mother attacks the newborn to kill her, as in the following picture: "she breaks down on the umbilical cord, biting it, and her face is covered in blood."

Women's personality in various situations is a negative recipient, who is unable to stop all forms of violence and chooses to flee or stand by watching without showing any intention to change the course of events. Although the daughter tries to change her fate in the story "Eve Cheats the Tale", in the end she is only a victim of violence by the father, mother, Society and herself, and therefore remains in the same circle of violence and cannot change her fate.

The character of the woman is absent and invisible and her voice is inaudible (Badran \& Cooke 1990; Tāhā, 2006). In "Dissoluteness" story, a woman is not present but receives all obscene looks without reacting or defending herself. As in "Scenes from a Comic Play", the mother receives all forms of violence and is left alone in the street, weak and bleeding without any help. If we compare this with the character of women in women's novels and stories of the last two decades, we find that women in Palestinian women's stories still suffer from all forms of violence and do not have any power to change the status quo, as in most very short stories written by men. We see that most of the characters in the stories of Palestinian female writers are far from heroic and do not make any progress or change (Soriano, 2021).

We can only say that the female Palestinian author of the very short stories reflects the personality of women in Arab society, which is still far from rebellion and revolution against social traditions and patriarchy manifested by the violation of taboos. There are few attempts by some female characters to break from this system, and these attempts are limited to rebellion against the marital institution and its consequences of a house, family, children and responsibilities. The Palestinian writer has moved away from political events and party affiliations in her writings, and started writing about war, rampant violence in society and social issues that affect her and the people.

\section{REFERENCES}

Al- 'at' ùt, S. (2016). [Online] Available: https://www.intelligentsia.tn

Al-Qallāzīn, S. (2011). [Online] Available: http://anfasse.org/next51-osaka/xmkb1240001152802/4450.html

Al-Ṣamādī, '. (2007). "Al-Qișṣah Al-Qașīrah Juddan bayna ushkāaliyyat Al-Muș̣alaḥ wa wuḍūḥ alrủyah", Dirāsāt, (Mujallad 34).

Badr L., (1979). Būṣalah min ’ajl ábbād Al-shams. Bayrūt: Al-MArkiz Al-Thaqāfĩ Al-árabī.

Badran M. \& Cooke M. (1990). Opening the Gates. London: Virago Press. 
Benmaśūd R. (2006). Jamāliyyat Al-Sard Al-Nisāàā, Al-dār Al-Bayḍāả: Shirkat Al-Nashr wa AlTawzî̀.

Cuddon, J.A. (1998). Literary Terms and Tineony, London: Clays Ltd.

Gottesfeld, D. (2013). "Forbidden Words": Palestinian Women's Literature in Israel-Between Conservation and Subversion".Hawwa, Journal of Women of the Middle East and the Islamic World, Vol. 11.

Gottesfeld, D. (2010). "A Compass for The Sunflower". Hawwa: Journal of Women of the Middle East and the Islamic World, Vol. 8.

Harpham, G. (1982). On The Grotesque. New Jeresy: Pricenton University Press.

Ḥamdāwī J. (2012). Al-Qissah Al-qașirah Jiddan Jins 'adabī Jadīd. Sidnī: Mủassasat Al-Muthaqqaf Al-arabī, adad Aghustus.

Mabrūk M. (1989). Al-Zawāhir Al-Faniyyah fi Al-Qișṣah Al-Qașīrah fi Maṣr 1967-1984. AlQāhirah: Al-Haỷah Al-Mașriyyah Al-āmmah Lil-Kitāab.

Nājī S. (2002). Al-Mar̉ah Al-Mașriyyah wa Al-Thawrah- Dirāsāt Tațbīqiyyah fi adab Al-Marah. AlQāahirah: Al-Majlis Al-álā Lil-Thaqāfah.

Shablāq, R. (1996). Tahawwulāt Al-Mujtamá fì Al-riwāayah Al-Falasțīniyyah. D.M: D.M.

Shawkī S. (1988). Bināả Al-Mufāraqah fi Al-Masrahiyyah Al-shíriyyah. Al-Qāhirah: îtrāk LilṬibăah wa Al-Nashr.

Soriano, R. (2021). The World's Hero: Gods and Archetypes in the Myth of the Superman. International Journal of Language \& Literary Studies, Vol. 3 NO.2.

Mīnū M. (2000). Fann Al-Qissah Al-qașīrah. Dubayy: Manshūrāt Dubayy.

Ṭāhā I. (2006). "Beware Men, They Are All Wild Animals" Arabic Feminist Literature: Challenge, Fight, and repudiation. Al-Karmil: Studies In Arabic Language And Literature, 27.

Tāhā, I. (2009). Arabic minimalist story. Wiesbaden: reichert.

Yates, W.\& James A. (1997). The Grotesque in Art and Literature: Theological Reflections. Michigan: Eerdmans Publishing Co.

Sarḥān, '. https://www.facebook.com/profile.php?id=100010207990224

\section{$\underline{\text { AUTHORS' BIO }}$}

Dr. Samah Saffouri Khoury has a Ph.D. in Arabic language and literature from Haifa University. The Ph.d dissertation deals with the distortion in the Palestinian very short story". She is a lecturer at Oranim college, and a coordinator and a teacher of Arabic Language in at Masar-Alternative school. She worked as pedagogical guide, and developed several digital units in Arabic language for high schools grade. She published 
several articles in Arabic and English that deal with different issues of the Arabic literature and language. 